An introduction to the tools and technique of cataloging, including RDA, subject cataloging, and MARC.

April 2-7, 2018

$\$ 175$

http://libraryjuiceacademy.com/005-intro-cataloging.php

\title{
Using MarcEdit
}

Library Juice Academy

Covering both basic functionality as well as more sophisticated uses, such as regular expressions and creating MARC records from vendor spreadsheet, this course is appropriate for both new and experienced users of MarcEdit.

June 4-29, 2018

$\$ 175$

http://libraryjuiceacademy.com/180-MarcEdit.php

Submitted by

Leslie Engelson, Metadata Librarian

Waterfield Library, Murray State University

\section{SELECTED ARTICLES FROM CURRENT LIBRARY JOURNALS}

Breeding, Marshall. "Open Source Library Systems: The Current State of the Art." Library Technology Reports 53, no. 6 (August/September, 2017): 5-35.

Flynn, Emily Alinder and Erin Kilkenny. "Cataloging from the Center: Improving e-Book Cataloging on a Consortial Level." Cataloging E Classification Quarterly 55, no. 7/8 (October 2017): 630-643.

Guay, Beth. "A Case Study on the Path to Resource Discovery." Information Technology E Libraries 36, no. 3 (September 2017): 18-48. DOI: 10.6017/ital.v36i3.9966 https://ejournals.bc.edu/ojs/index.php/ital/article/view/9966

Harveland, Jennifer. "Library Inventory Methods: Using Flexibility and Creativity to Achieve a Common Goal Within a Federated Library System." Collaborative Librarianship 9, no. 3 (July 2017): 1-13. https://digitalcommons. du.edu/collaborativelibrarianship/vo19/iss3/4

Hoeppner, Athena. "Database Lists A to Z: A Practitioner's Tips and Caveats for Managing Database Lists." Serials Librarian 73, no. 1 (September 2017): 27-43.

Ndungu, Miriam Wanjiku. "Bibliographic Control of Theses and Dissertations in Kenya." Library Review 66, no. 6 (2017): 523-534.

O'Neill, Edward T., Kerre A. Kammerer, and Rick Bennett. "The Aboutness of Words." Journal of the Association for Information Science E Technology 68, no. 10 (October 2017): 2471-2483.

Robbeloth, Hilary, Matthew Ragucci, and Kristina DeShazo. "Evidence-Based Acquisition: A Real Life Account of Managing the Program within the Orbis Cascade Alliance." Serials Librarian 73, no. 3/4 (November 2017): 240-247.

Schultz, William N. and Lindsay Braddy. "A Librarian-Centered Study of Perceptions of Subject Terms and Controlled Vocabulary." Cataloging E Classification Quarterly 55, no. 7/8 (October 2017): 456-466.

Strader, C. Rockelle. "From User Tasks to User Services: Placing the Functional Requirements for Bibliographic Records Models into a Larger Framework." Technical Services Quarterly 34, no. 4 (October 2017): 347-368.

Szostak, Rick. "A Grammatical Approach to Subject Classification in Museums." Knowledge Organization 44, no. 7 (November 15, 2017): 494-505.

Ullah, Asim, Shah Khusro, and Irfan Ullah. "Bibliographic Classification in the Digital Age: Current Trends and Future Directions." Information Technology and Libraries (Online) 36, no. 3 (September 2017): 48-77. DOI: 10.6017/ital. v36i3.8930 https://ejournals.bc.edu/ojs/index.php/ital/article/view/8930

Wahl, Mary. "Full Stream Ahead: Designing a Collection Development Workflow for Streaming Video Content." Library Resources EO Technical Services 61, no. 4 (October 2017): 226-236. 
Weng, Cathy and Erin Ackerman. "Towards Sustainable Partnership: Examining Cross Perceptions of Public and

Technical Services Academic Librarians." Library Resources EO Technical Services 61, no. 4 (October 2017): 198-211.

Submitted by

Anna Appleman, Cataloger

John Bulow Campbell Library, Columbia Theological Seminary

\section{TESTIMONY}

\section{The San Miguel Library: A Bicultural Library in a Bicultural Town}

I hadn't expected it to be a busman's holiday. I had run off for a week to San Miguel de Allende, Mexico, in hopes of sorting out some personal issues and properly grieving for my recently departed dad. In short, I just needed to get away from it all to be still and quiet. But I had heard that San Miguel's public library had some spectacular murals on its ceilings and walls. Surely, I thought, it wouldn't upset my serenity to stroll over there and take a peek. I ended up visiting the library three times, spending hours taking photos, and interviewing librarians.

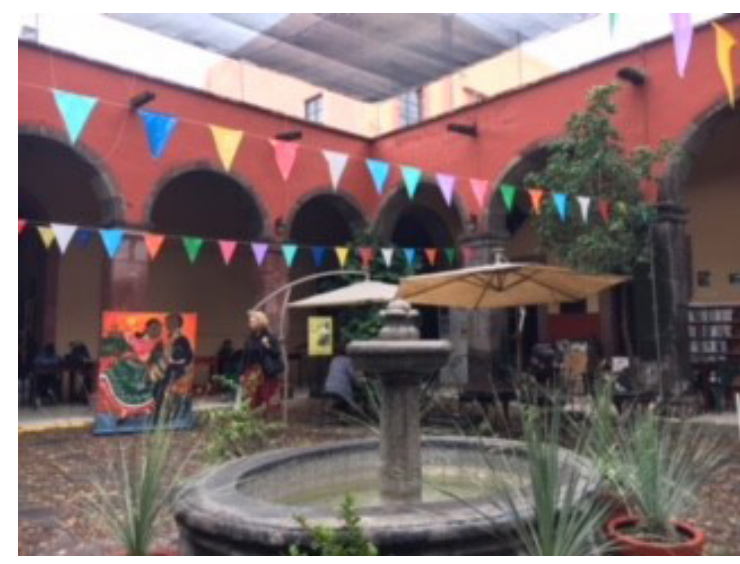

The central courtyard.

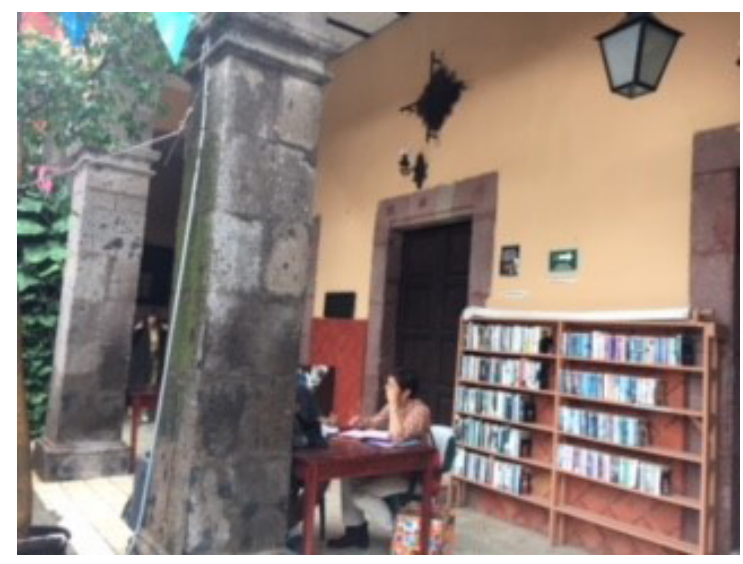

A private English class in the open-air portico.

\section{A Unique Design}

Although the front of the building says Biblioteca Pública ("Public Library"), the library's official, legal name is Biblioteca Pública de San Miguel de Allende, A.C. The "A.C." means Asociación Civil, meaning a not-for-profit.

The library is situated around a central courtyard where people can sit and read at umbrellaed tables - even on a rainy day, which it was when I first visited. From the courtyard, visitors can stroll through a wide, covered portico - U-shaped and lined with columns — into the book rooms.

The portico itself functions as a multi-purpose people space with benches, long tables with chairs, and small, two-person tables. Some of the activities going on there on a random summer day were: teenagers chattering animatedly, students studying quietly, a woman teaching English to a middle-aged man, and two artists selling their paintings and handcrafts.

Besides the book rooms, the library has a bookstore, a restaurant, a room for programs and presentations, a theater for performances, and a cut-rate shopping space. It wasn't long before I laid eyes on the much-heralded murals.

Just to the left of the entrance, one's eyes are irresistibly drawn to a luscious palette of reds, oranges, and sepia tones - the ceiling and walls of the bookstore. When the bookstore manager told me the artist's name, I was momentarily confused - was it Jacques-Louis David? or Leonardo da Vinci? In fact, it was Mexican artist David Leonardo, whose murals also adorn the Sala Quetzal, one of the library's presentation spaces.

\section{Expats Open a Library}

San Miguel's library reflects its community. The town itself is thoroughly bicultural, with American, Canadian, and European expatriates a part of the local ambience. After World War II, San Miguel's Instituto Allende attracted many former soldiers seeking an education on the GI bill. (It was an approved institution by the U.S. Department of Veterans Affairs.) Many veterans stayed; meanwhile, artists began drifting into San Miguel (including, at various times, Diego Rivera and Frida 